\title{
Hilar cell tumour of the ovary
}

\author{
M. C. ANDERSON \\ From the Departments of Pathology, St Mary's Hospital Medical School, and the Samaritan Hospital \\ for Women, London
}

SYNOPSIS The case of a 42-year-old woman with virilization, hirsutes, and a high level of circulating testosterone is described. A hilar cell tumour of the ovary was found, the histological features of which were typical, with the presence of crystalloids of Reinke, hyaline bodies, lipid, and lipofuscin. Some areas showed appearances similar to those seen in 'adrenocortical cell' tumours. In common with other lipid cell tumours of the ovary, hilar cell tumours most probably arise from mesenchymal elements and the group should, therefore, be considered as a subdivision of the gonadal stromal (sex cord-mesenchymal) tumours.

Hilar cell tumours are among the rarest neoplasms of the ovary. The first case was recorded by Berger in 1942. Dunnihoo, Grieme, and Woolf (1969), reviewing the world literature, found 47 cases and added three more. Since then a few further cases have been added (Green and Maqueo, 1966; Hughesdon, 1966; Salm, 1967; Echt and Hadd, 1968; Allander and Wägermark, 1969; Mori, Yoshida, Nishimura, Kono, Yamada, and Tatsumi, 1970) bringing the total to about 60 . This is a report of a further case of pure hilar cell tumour of the ovary producing virilization and a discussion of the origin of the tumour.

\section{Report of a Case}

The patient was a 42-year-old Turkish woman who was first seen in September 1970, complaining of loss of scalp hair for seven years and progressive increase in body hair for three years. She had had no pregnancies. In 1951 she underwent hysterectomy in another country, the reasons for which are not clear, although she thinks there was an abdominal tumour. In 1968 a pleomorphic adenoma of the right parotid was partly removed.

On examination there was loss of hair from the frontal region of the scalp and temporal recession. Body hair was generally increased, particularly on the back, shoulder, and limbs. An acneiform rash was present on the face and the skin was greasy. The clitoris and labia were enlarged and the vagina and cervix appeared slightly atrophic. Examination under anaesthetic revealed an enlarged right ovary Received for publication 9 June 1971. and this finding was confirmed laparoscopically. A laparotomy was performed, at which both ovaries were found to be adherent to the floor of the pelvis and the cervical stump was covered by peritoneum

Other abdominal organs were palpated and $n \propto$ abnormalities were found. Bilateral salpingo oophorectomy was performed.

\section{Biochemical Investigations}

The results of hormone estimations on the peripheral bloodare shown in the Table. Cortisol suppression by dexamethasone was normal and urinary excretion of 17-ketosteroids and 17-ketogenic steroids was not increased.

\begin{tabular}{llll}
\hline & $\begin{array}{l}\text { Testosterone } \\
(\mathrm{ng} \%)\end{array}$ & $\begin{array}{l}\text { Androstenedione } \\
(\mathrm{ng} \%)\end{array}$ & $\begin{array}{l}\text { Cortisol } \\
(\mu \mathrm{g} \%)\end{array}$ \\
\hline $\begin{array}{l}\text { Preoperative } \\
\text { Postoperative }\end{array}$ & 15250 & $123-188$ & 12 \\
Normal female range & $15-70$ & 58 & $\frac{6}{6-22}$ \\
\hline
\end{tabular}

Table Peripheral plasma hormone values

\section{Gross Pathology}

The Fallopian tubes were slightly thickened and fibrous adhesions were present on their surfaces. The right tube was closely bound to the right ovary by firm adhesions and some adhesions were also present on the surface of the ovary, which was enlarged $(3 \times 2.5 \times 2.5 \mathrm{~cm})$. Bisection revealed the presence of a tumour $(2.5 \mathrm{~cm}$ in diameter) occupying the medial two-thirds of the ovary. The tumour was 


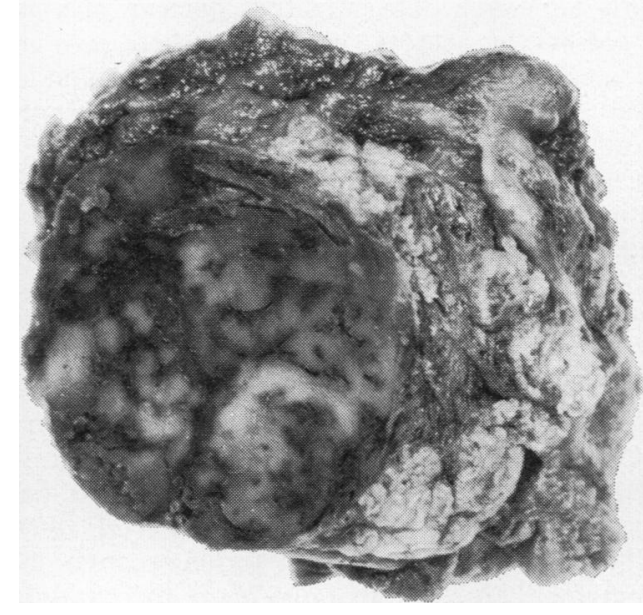

Fig. 1 Section through middle of tumour and surrounding ovary, in which the corpora albicantia can be clearly seen. The Fallopian tube is on the right $(\times 3)$.

almost spherical and well circumscribed although not encapsulated. In the unfixed state it was soft and almost gelatinous and its cut surface (Fig. 1) presented a variegated appearance, with haemorrhagic areas separating greyish brown, semitranslucent tissue. The ovarian tissue surrounding the tumour contained prominent corpora albicantia. The left ovary was of normal size for the age of the patient and also contained many prominent corpora albicantia.

\section{Microscopy}

The tissue was fixed in Bouin's fluid and paraffin sections were stained using haematoxylin and eosin, van Gieson, periodic acid-Schiff reaction, Heidenhain's iron haematoxylin, Perl's Prussian blue reaction, and Ziehl-Neelsen stain with prolonged exposure to carbol fuchsin. Frozen sections of fixed tissue were stained with oil red $\mathbf{O}$ for lipid.

The tumour consisted of solid, fairly homogeneous masses of cells, separated by slender fibrous trabeculae and areas of haemorrhage. The cells were closely spaced typical hilar cells with round vesicular nuclei and prominent nucleoli (Fig. 2). Most cells had granular, eosinophilic cytoplasm although in some areas the cells were rather larger with clear cytoplasm (Fig. 3).

Four types of inclusion were present. Many cells contained lipid, as demonstrated by oil red $\mathbf{O}$, and in most of these cells the fat was distributed as many small particles. A few cells, however, contained single, large, fatty bodies. Many cells also contained

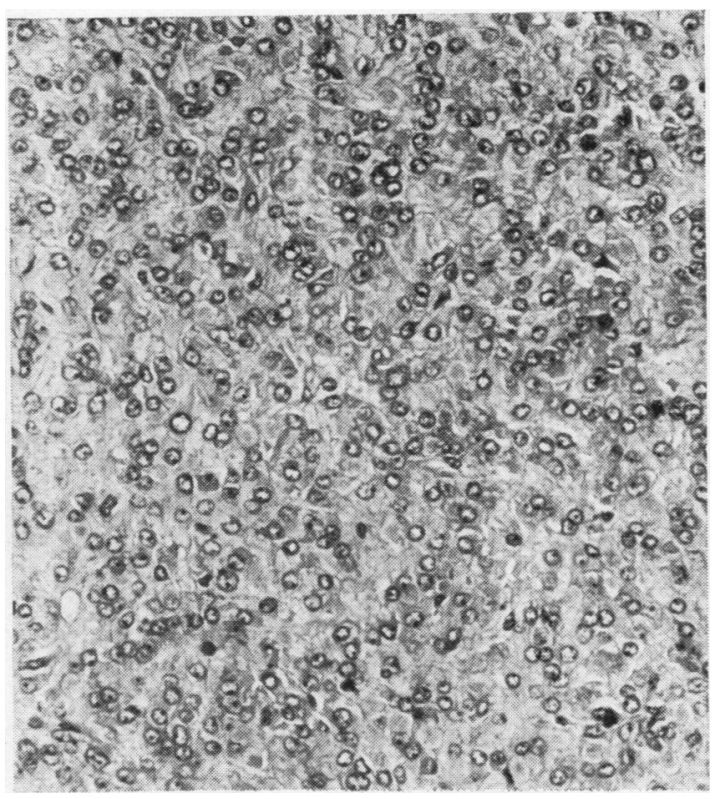

Fig. 2 Section from a typical area of the tumour, showing indistinct cell outlines and regular, round nuclei (haematoxylin and eosin, $\times 365$ ).

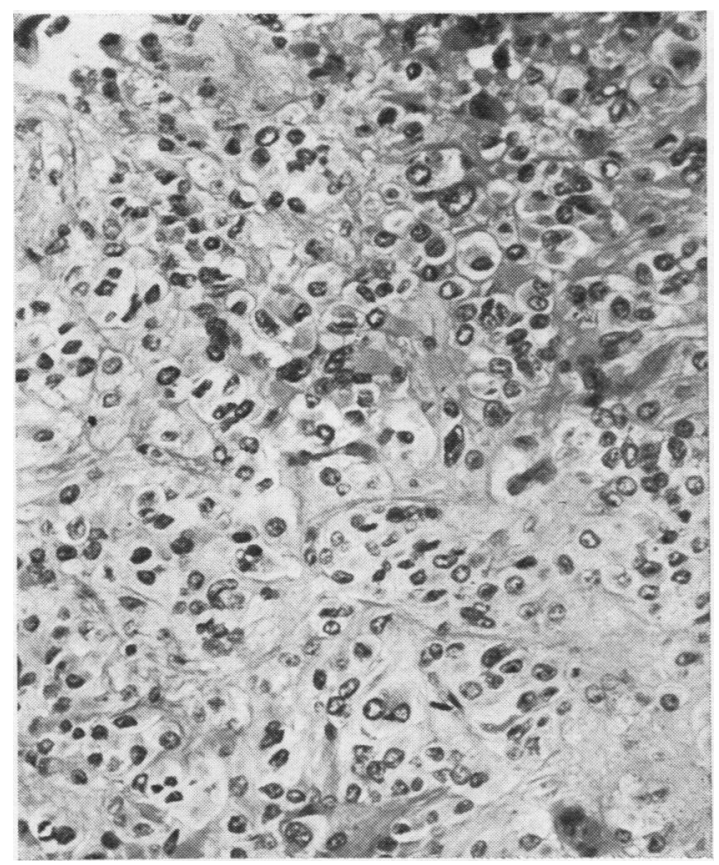

Fig. 3 An area containing rather larger cells with clear, vacuolated cytoplasm, reminiscent of the cells seen in adrenocortical cell tumours (haematoxylin and eosin, $\times 310$ ). 


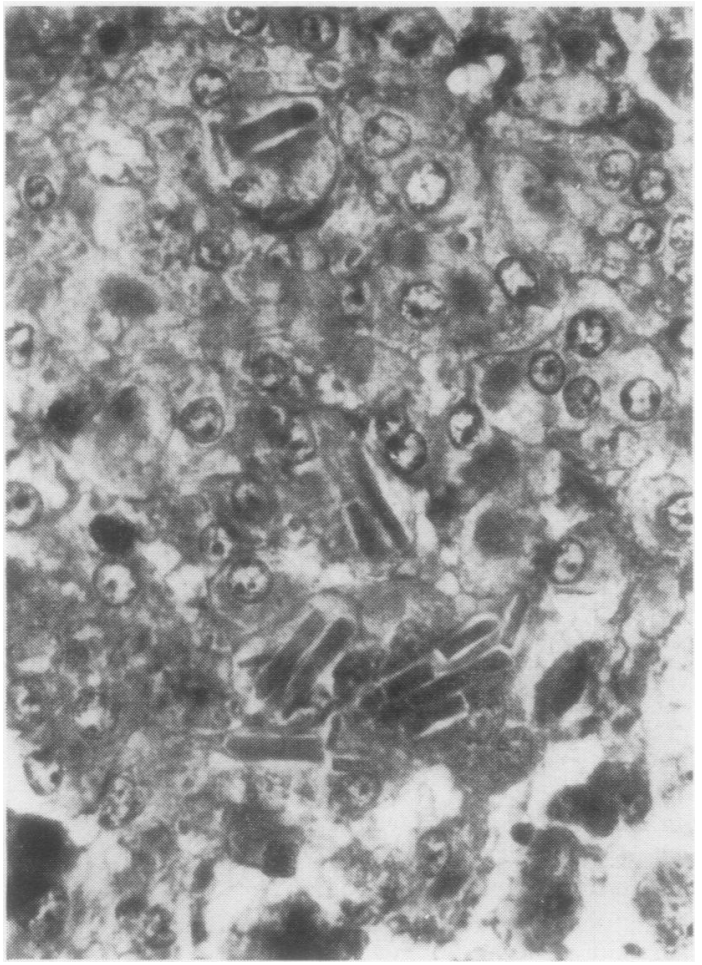

Fig. 4 An area containing many Reinke crystalloids and prominent spherical 'hyaline bodies' (Heidenhain's iron haematoxylin, $\times 960$ ).

hyaline, spherical bodies, which stained grey with Heidenhain's iron haematoxylin and had indistinct outlines. These inclusions were fairly evenly distributed throughout the neoplasm. The third type of inclusion present was the Reinke body. These are rod-like bodies, usually with square ends, which may be as long as the long axis of the cell, and, like the hyaline bodies, stained grey-black with Heidenhain's iron haematoxylin. They were present only in a small proportion of cells but their distribution was uneven, so that as many as 15 were found in a small group of cells in one high-power field (Fig. 4). A few tumour cells also contained golden-brown pigment which stained with carbol fuchsin but did not give the Prussian blue reaction. Also present were collections of macrophages, mainly along the fibrous septa but also scattered amongst the tumour cells themselves, containing pigments which stained with PAS and carbol fuchsin and also gave the Prussian blue reaction. Some of these cells contained fat.

The tumour was not encapsulated and microscopically its edges were poorly defined, the tumour cells infiltrating a short distance into the adjacent corpora albicantia. Degenerative nuclear changes were present in necrotic areas, but there was no histological evidence of malignancy. The remainder of the right ovary contained many corpora albicantia and a few germinal inclusion cysts.

The left ovary also contained corpora albicantia and germinal inclusion cysts. No hilar cells, normal or abnormal, were seen in multiple sections.

\section{Discussion}

This case demonstrates all the features, both clinical and histological, of a typical hilar cell tumour. Usually considered to be of particular interest and importance are the Reinke crystalloids and it has been proposed (Scully, 1963; Dunnihoo et al, 1969) that the diagnosis of hilar cell tumour cannot be made in their absence. In only 26 of the cases of hilar cell tumour reported in the literature have crystalloids been demonstrated, so that if they are taken as essential for diagnosis, the tumour is indeed rare. In this respect, three comments seem appropriate. First, the distribution of the crystalloids is very uneven, so that the chances of finding them depend upon luck and the number of sections examined. Thus, there must be a number of cases which contain these bodies but the sections examined happened not to include the areas containing them. The present case was fixed in Bouin's fluid, which may make identification easier (Dunnihoo et al, 1969). Secondly, some of the areas in this case consisted of large cells with pale cytoplasm, very similar to those found in adrenocortical cell tumours. Taylor and Norris (1967) and Teter, Nadworny, Zachwiezj, and Bartoszewicz (1961) have commented on the occurrence of cells of this type in tumours that would otherwise be typical hilar cell tumours and have suggested that their presence means that the lipoid cell tumours are not a heterogeneous group and should not be subdivided. Teilum (1971) illustrates a malignant Leydig cell tumour of the testis, a retroperitoneal metastasis of which contains polyhedral cells with eosinophilic cytoplasm as well as highly vacuolated cells with clear cytoplasm. This raises the question of whether it is justifiable to designate a tumour as of hilar cell type, even if it contains Reinke crystalloids, if other areas have adrenocortical cell appearances. Thirdly, Scully and Cohen (1961) have demonstrated the presence of Reinke crystalloids in the cells of a tumour of the adrenal medulla. One explanation of this is that cells other than hilar cells may contain crystalloids.

The exact place of hilar (Leydig) cell tumours in the classification of ovarian neoplasms is not clear. Th:y are usually included in the group of lipoid cell tumours, together with 'adrenocortical cell' 
tumours and luteomas. These tumours have in common a general endocrine architecture with oval or polyhedral cells whose cytoplasm contains a greater or lesser quantity of lipids (Gricouroff and Veith, 1968). Alternatively, tumours of hilar cells can be included in the broad category of gonadal stromal tumours, occurring as a one-sided development of the Sertoli-Leydig cell tumour (arrhenoblastoma or androblastoma) (Scully, 1968).

Any attempt to reconcile these apparently different views must depend to some extent on what is thought to be the histogenesis of the tumours. Sternberg (1949) found hilar cells in $80 \%$ of adult ovaries, distributed in irregularly scattered clumps in the hilus and mesovarium, often surrounding vessels and non-myelinated nerves. The origin of hilar cells in the normal ovary is in question. There have been suggestions that they are vestiges of male structures, remnants of a time when the ovary went through a testicular stage in its development (Teter et al, 1961). A more reasonable concept is that they arise from undifferentiated mesenchyme (Merrill, 1959), as is the case in the testis. Thus, there is envisaged a continuous differentiation of hilar cells from ovarian mesenchyme throughout life, a process which may be more active at some times than at others. Groups of hilar cells have been found in the cortex of the ovary (Merrill, 1959), as well as in the hilum, so it must be concluded that some cortical stromal cells are capable of differentiating into hilar cells. Whether hilar cell tumours arise from preexisting hilar cells (Morris and Scully, 1958; Abell and Holtz, 1965; Salm, 1967) or whether they arise directly from the stroma (Hughesdon, 1966; Taylor and Norris, 1967) seems of little consequence if it is agreed that the hilar cells themselves arise from ovarian mesenchyme (Merrill, 1959; Allander and Wägermark, 1969).

Examination of Sertoli-Leydig cell tumours by light microscopy and electron microscopy (Berendsen, Smith, Abell, and Jaffe, 1969) has shown cells identical in appearance to the cells found in hilar cell tumours (Green and Maqueo, 1966) and also to testicular Leydig cells. Jenson and Fechner (1969) claim that these cells must be derived directly from the ovarian stroma, although other workers (Morris and Scully, 1958; Abell and Holtz, 1965) again prefer an origin from hilar elements.

The evidence therefore suggests that hilar cell tumours and the Leydig cell element of Sertoli-Leydig cell tumours are identical both in appearance and histogenesis and so it seems reasonable to include them both in the same category of a histogenetic classification, that is, as gonadal stromal tumours.

The continued use of the category of lipoid cell tumour is advocated because tumours in this category can be so similar in appearance and contain cell types so mixed that a more specific assignment becomes difficult (Taylor and Norris, 1967). There seems to be sufficient evidence, however (Hughesdon, 1966; Taylor and Norris, 1967), for the origin of lipoid cell tumours of all types from the ovarian stroma rather than, for example, from adrenal rests. It seems best, therefore, that the term 'lipoid cell tumour' should be retained but that not only hilar cell tumours but this whole group should form a subdivision of gonadal stromal tumours.

I should like to thank Mr G. D. Pinker for permission to publish this case.

\section{Referenees}

Abell, M. R., and Holtz, F. (1965). Ovarian neoplaims in childhood and adolescence. 2. Tumors of non-germ cell origin. Amer. J. Obstet. Gynec., 93, 850-66.

Allander, E., and Wägermark, J. (1969). Leydig cell tumours of the ovary. Report of three cases. Acta obstet. gynec. scand., 48, 433-439.

Berendsen, P. B., Smith, E. B., Abell, M. R., and Jaffe, R. B. (1969). Fine structure of Leydig cells from an arrhenoblastoma of the ovary. Amer. J. Obstet. Gynec., 103, 192-199.

Berger, L. (1942). Tumeur das cellule; sympathicotropes de l'ovaire avec virilisation. Rev. canad. Biol., 1, 539-566.

Dunnihoo, D. R., Grieme, D. L., and Woolf, R. B. (1969). Hilar cell tumours of the ovary. Report of two new cases and a review of the world literature. Obstet. and Gynec., 27, 703-713.

Echt, C. R., and Hadd, H. E. (1968). Androgen excretion patterns in a patient with a metastatic hilus cell tumour of the ovary. Amer. J. Obstet. Gynec., 100, 1055-1061.

Green, J. A., and Maqueo, M. (1966). Histopathology and ultrastructure of an ovarian hilar cell tumor. Amer. J. Obstet. Gynec., 96, 478-485.

Gricouroff, G., and Veith, F. (1968). Lipoidic cell tumors of the ovary. In Ovarian Cancer (UICC Monograph Series, Vol. 11), edited by F. Gentil and A. C. Junquiera, pp. 74-86. Springcr, Barlin.

Hughesdon, P. E. (1966). Ovarian lipoid and theca cell tumours; their origins and interrelations. Obstet. Gynec. Surv., 21, 245-288.

Jenson, A. B., and Fechner, R. E. (1969). Ultrastructure of an intermediate Sertoli-Leydig cell tumor. Lab. Invest., 21, 527-535.

Merrill, J. A. (1959). Ovarian hilus cells. Amer. J. Obstet. Gynec., 78, 1258-1271.

Mori, T., Yoshida, Y., Nishimura, T., Kono, T., Yamada, S., and Tatsumi, S. (1970). Clinical and bioshemical studies of a patient with a hilus cell tumour. $J$. Endocr., 47, 13-20.

Morris, J. M., and Scully, R. E. (1958). Endocrine Pathology of the Ovary. Mosby, St Louis.

Salm, R. (1967). Pure and mixed hilus cell tumours of the ovary. Arris and Gale lecture delivered at the Royal College of Surgeons of England on 14th November 1966. Ann. Roy. Coll. Surg. Engl., 41, 344-363.

Scully, R. E. (1963). Androgenic lesions of the ovary. In The Ovary, (International Academy of Pathology, Monograph No. 3) edited, by H. G. Grady and D. E.Smith, pp. 143-174. Williams and Wilkins, Baltimore.

Scully, R. E. (1968). Sex cord-mesenchyme tumours. Pathological classification and its relation to prognosis and treatment. In Ovarian Cancer (UICC) Monograph Series, Vol. 11), edited by F. Gentil and A. C. Junquiera, pp. 40-57. Springer, Berlin.

Scully, R. E., and Cohen, R. B. (1961). Ganglioneuroma of adrenal medulla containing cells morphologically identical to hilus cells. Cancer (Philad.), 14, 421-425.

Sternberg, W. H. (1949). The morphology, androgenic function. hyperplasia and tumors of the human ovarian hilus cells, (Extraparenchymal Leydig cells). Amer. J. Path., 25, 493-522. 
Taylor, H. B., and Norris, H. J. (1967). Lipid cell tumors of the ovary. Cancer (Philad.). 20, 1953-1962.

Teilum, G. (1971). Special Tumors of Ovary and Testis. pp. 102-106, 198-201. Munksgaard, Copenhagen.
Teter, J., Nadworny, J., Zachwiezj, E., and Bartoszewicz, W. (1961). Interstitial cell tumour of ovary with virilism detected pre- $\frac{\sigma_{+}}{+}$ operatively with the help of endocrinological methods. $J . \vec{\nabla}$ Obstet. Gynaec., Brit. Commwlth, 68, 451-458. 